\title{
Application of Healthy and Safe Internet in Controlling Negative Internet Impacts for Students at MI Darussa'adah, South Jakarta.
}

\section{HERI SATRIA SETIAWAN, RUDI HERMAWAN, RUDI APRIYADI RAHARJO}

\author{
Universitas Indraprasta, Jakarta, Indonesia \\ Email : herisatria20@gmail.com
}

Received 10 September 2021 | Revised 18 November 2021 | Accepted 18 November 2021

\begin{abstract}
The use of gadgets today has become a major requirement for everyone. In the present, many children are using gadget since childhood especially to watch videos on youtube, play online games, and search for learning materials through the help of the internet. This can be a good step so that children easily adapt to technological developments. But on the other hand, parents must worry if children play gadgets too often and access things that are not age-appropriate, which is not necessarily suitable for their age. It is important for parents to monitor the use of gadgets in children. The role of parents and teachers in dealing with this situation, they must have the ability to monitor and control the use of the internet by parental control applications. It is able to select, limit, and supervise what applications can be accessed by children and adolescents so they can still use gadgets as a learning and entertainment medium without having to be addicted and poisoned by negative content.
\end{abstract}

Keywords: healthy and safe internet; parental control; gadget.

\section{INTRODUCTION}

Healthy and Safe Internet (INSAN) is a positive internet use program in the community launched by the Ministry of Communication and Information of the Republic of Indonesia. The use of the internet in Indonesia has grown rapidly along with the development of the use of mobile phone devices in various age groups today. Mobile phone devices, in this case based on Android, have grown quite rapidly, supported by the implementation of cheap internet in Indonesia. These developments make the number of internet literacy in Indonesia has reached more than 150 million. The development of the world of mobile phones and the internet in Indonesia also reaches school age children. Where nowadays many school-age children are seen using mobile phones that are also connected to the internet. For schoolage children, they often use game applications or online games and social media in their activities using the internet. In fact, many of them also use YouTube video streaming as one 
of the applications they often see. Seeing this phenomenon, school-age children can access various kinds of applications and information, making them very vulnerable to the absorption of all negative content and information. Which later can have a negative impact on the mental development of children (Donny dan Merry, 2009).

The role of parents and teachers in dealing with this situation must have the ability to supervise and control the use of the internet, especially in the use of mobile phones. Parents must have the ability to use parental control applications. Kakatu application is a startup from Bandung that makes parental control applications specifically for Android to select, limit, and monitor what applications children and teenagers can access. Current conditions and phenomena Many school-age children have their own mobile phones. With lower prices and better internet connections as well as the many applications that support games and social media based on Android, making mobile phone devices something very attractive for their age. And the current condition of parents buying cell phones for their children because they love their children and can't bear to see their children not having cell phones because the environment around their friends' children already have cell phones (Isa et al, 2016).

Educating teenagers is like playing a kite, whose movement in the sky must be monitored from time to time, occasionally we need to tug on the threads so that the kite's agile movements remain beautiful but not swayed by the wind. If the thread breaks from the owner, then no doubt, the kite will fly and cannot be saved. The same is true for educating teenagers. They are individuals at this age who have the desire to be free to create, determine their social choices, determine future choices and many things that are likely to be contrary to the expectations of their parents. But that's teenagers, they don't want confinement for what they do. Parents and the environment should understand this situation by giving appreciation for their opinions, giving them the freedom to develop, but still positioning themselves as a control over the growth and development of teenagers. If they are too limited, they will give an attitude of resistance to their parents, on the contrary, their omission in freedom will also have a negative impact on their personality development. The most appropriate attitude of parents is to let them be free but still in control (Rizal dan Herry, 2014).

One of the trends of teenagers today is the use of cyberworld through internet access. The use of cyberworld for teenagers has become a daily 'basic need' that can make them neglect their food needs in order to meet the need to be in contact with the cyberworld (Rizky Choiru, 2014). Building relationships through social networks and obtaining various information with quick access are goals that teenagers want to achieve through cyberworld. To be able to access internet services is no longer an obstacle for teenagers, the availability of mobile phones equipped with software that provides services to access the internet is no longer a foreign thing for teenagers. With this convenience, teenagers can access the internet anywhere (Sinta Isabella, 2016).

\section{METODH}

The activity was carried out using the interview method and direct observation on the subject of teachers and parents of students. Information was obtained for the purpose of community service activity (abdimas) in the form of the problem of lack of knowledge regarding supervision of children in playing the internet or smartphones with the following stages: 
Application of Healthy and Safe Internet in Controlling Negative Internet Impacts for Students at MI Darussa'adah, South Jakarta.

1. Beginning of implementation

Information and data collection was carried out, library research was carried out by looking for materials needed to be presented to teachers and parents, needs analysis to support the implementation of activities.

2. Implementation

The implementation took place at Madrasah Darussa'adah which was located on Jalan Poncol Jaya No. 41 Kuningan Barat, South Jakarta. This seminar and discussion is intended for teachers and parents in the MI Darussa'adah environment with the following implementation methods:

The focus of the material in this seminar is the application of the "Kakatu" application in the use of a Healthy and Safe Internet (INSAN) for teachers and parents of students in controlling the negative impact of internet use on students and children (Parenting Indonesia, 2015). In the seminar, there were 2 presentations of material, namely,

a. Material I, Healthy and Safe Internet for Children.

b. Material II, Implementation of Kakatu Application as a Safe Launcher for Children.

The first material, Healthy and Safe Internet for Children, describes how internet technology that can be consumed by children is mixed between good content and bad content. Children have not been able to sort out how he should filter the content on the internet (Parenting Indonesia, 2014). The role of parents and teachers must be increased to better know the two sides of the internet, parents and teachers must know more about the positive benefits of the internet. From the explanation of the first material, it is explained how bad content is easily accessed by internet users. And also explained how to counter negative content into positive internet use for children.

The second material, Implementation of the Kakatu Application as a Safe Launcher for Children, this material provides knowledge in safe internet use for children. Where Kakatu Launcher is very safe for children with various age levels of children. Parents can set what applications are allowed to be accessed by children, play time that can be set, the location of the child's whereabouts while playing using a smartphone device.

\section{Post Implementation}

Activities in the form of evaluating activities, compiling reports and making final reports Madrasah Darussa'adah Jakarta is a religion-based basic education institution located on Jalan Poncol Jaya No. 41 Kuningan Barat, South Jakarta. The location of the Madrasah which is located in a densely populated residential area with various ethnic groups and various economic strata makes Darussa'adah students unique and diverse in the behavior of their students. In the use of smartphone technology, many of the students here use game applications, social media, and video streaming services.

The Vision and Mission of Madrasah Darussa'adah Jakarta include:

Vision: To become an educational institution that is able to build a personality image of students who have diniyah integrity (spiritual intelligence), scientific integrity (intellectual intelligence), and insaniyah intelligence (emotional intelligence).

Mission: 1. Implement Islamic religious education programs to develop the basic potential of fitri (oneness).

2. Implement values education programs for social, national and humanitarian life.

3. Develop education based on the development of multiple intelligences. 


\section{RESULTS AND DISCUSSION}

The implementation took place at Madrasah Darussa'adah which was located on Jalan Poncol Jaya No. 41 Kuningan Barat, South Jakarta (showed at Figure 1). With this activity in the form of seminars and joint discussions between parents and teachers in the Madrasah Darussa'adah Jakarta regarding the use of healthy and safe internet by utilizing the kakatu application, it is hoped that, among others:

1. Parents and teachers must know and be smarter about technology and internet applications than their children or students.

2. Parents and teachers must accompany their children in using internet applications.

3. Parents and teachers should know how to control internet/smartphone usage.

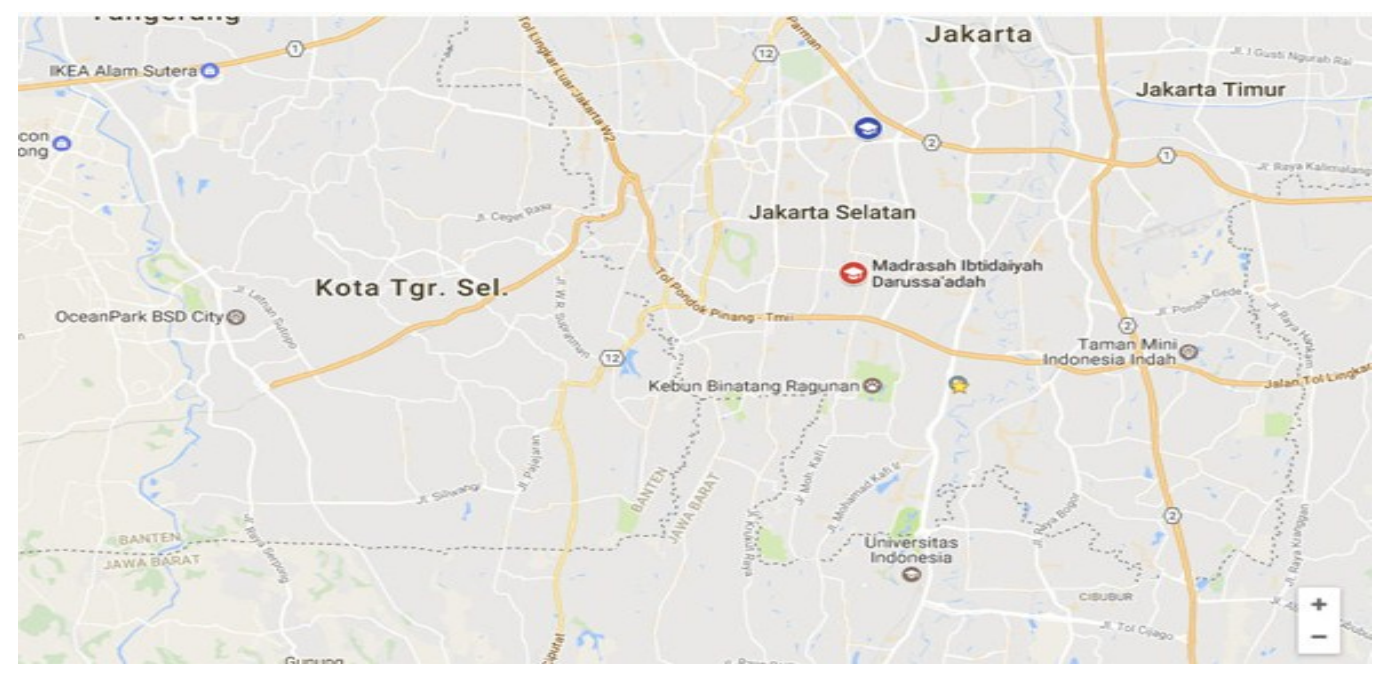

Figure 1. Partner Location Map Website

\section{Benarkah penggunaan Internet bermanfaat bagi anak ???}

\section{[Bisa lya]}

Bila digunakan secara bijak, ada banyak sekali manfaat positif pengunaan internet bagi anak.

\section{[Bisa Tidak]}

disisi lain banyak juga unsur buruk yang terletak pada internet. Seperti konten pornografi, konten kekerasan atau bahasa-bahasa kasar yang akan berdampak buruk untuk pertumbuhan anak. Ada Bahava internet bagi anak yang dapat merusak masa depan anak kita.

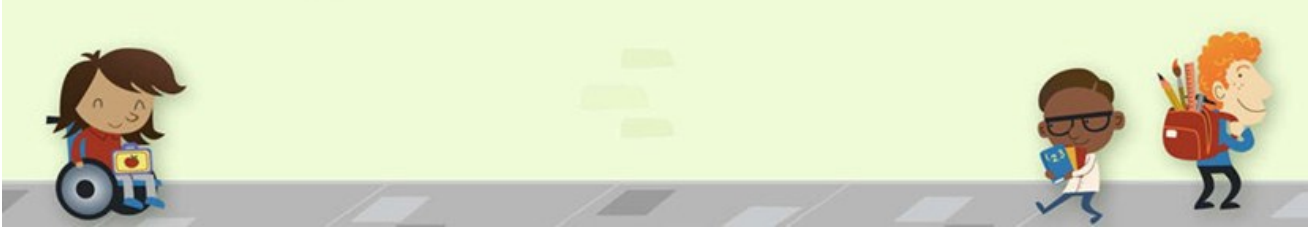

Figure 2. Abdimas Material

Figure 2 above shows that the internet has benefit impact for children in a positive way in the form of training children in contextual learning using digital, while the negative impact is 
Application of Healthy and Safe Internet in Controlling Negative Internet Impacts for Students at MI Darussa'adah, South Jakarta.

in the form of pornographic content, violent content or abusive language which has a negative impact on children's development.

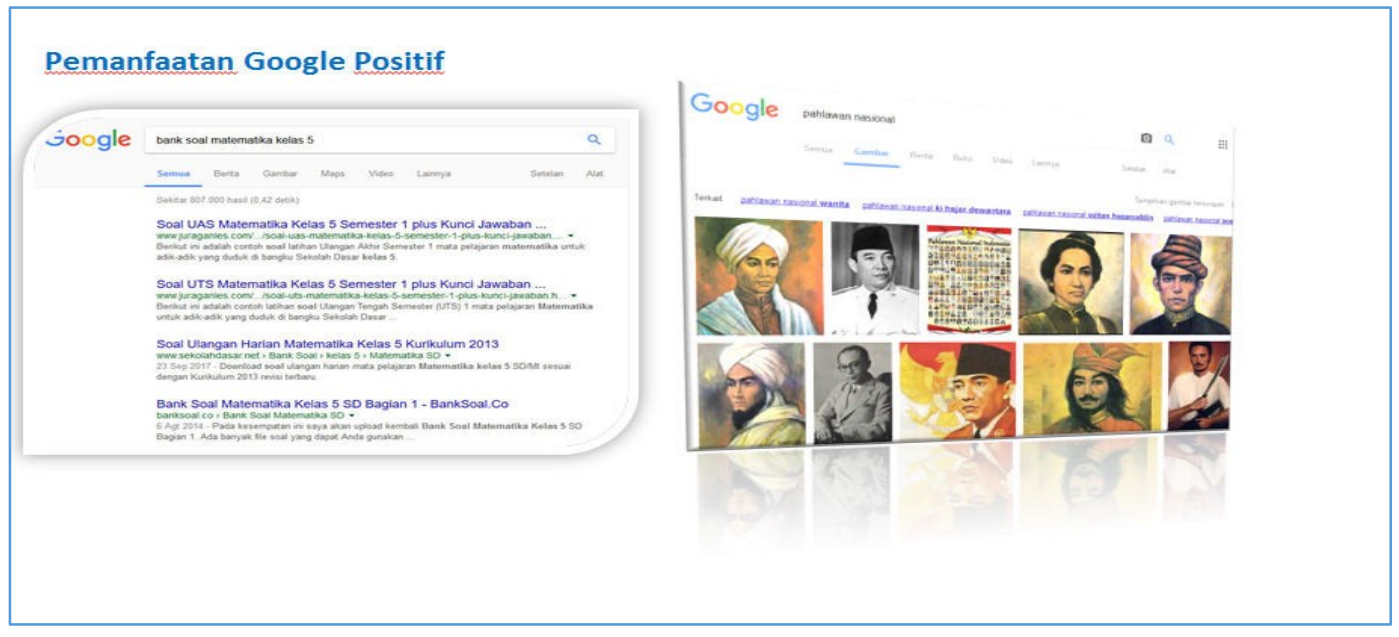

Figure 3. Abdimas Material

Figure 3 above is positive in terms of finding practice questions, pictures of heroes, or other lessons that have a positive impact on children.

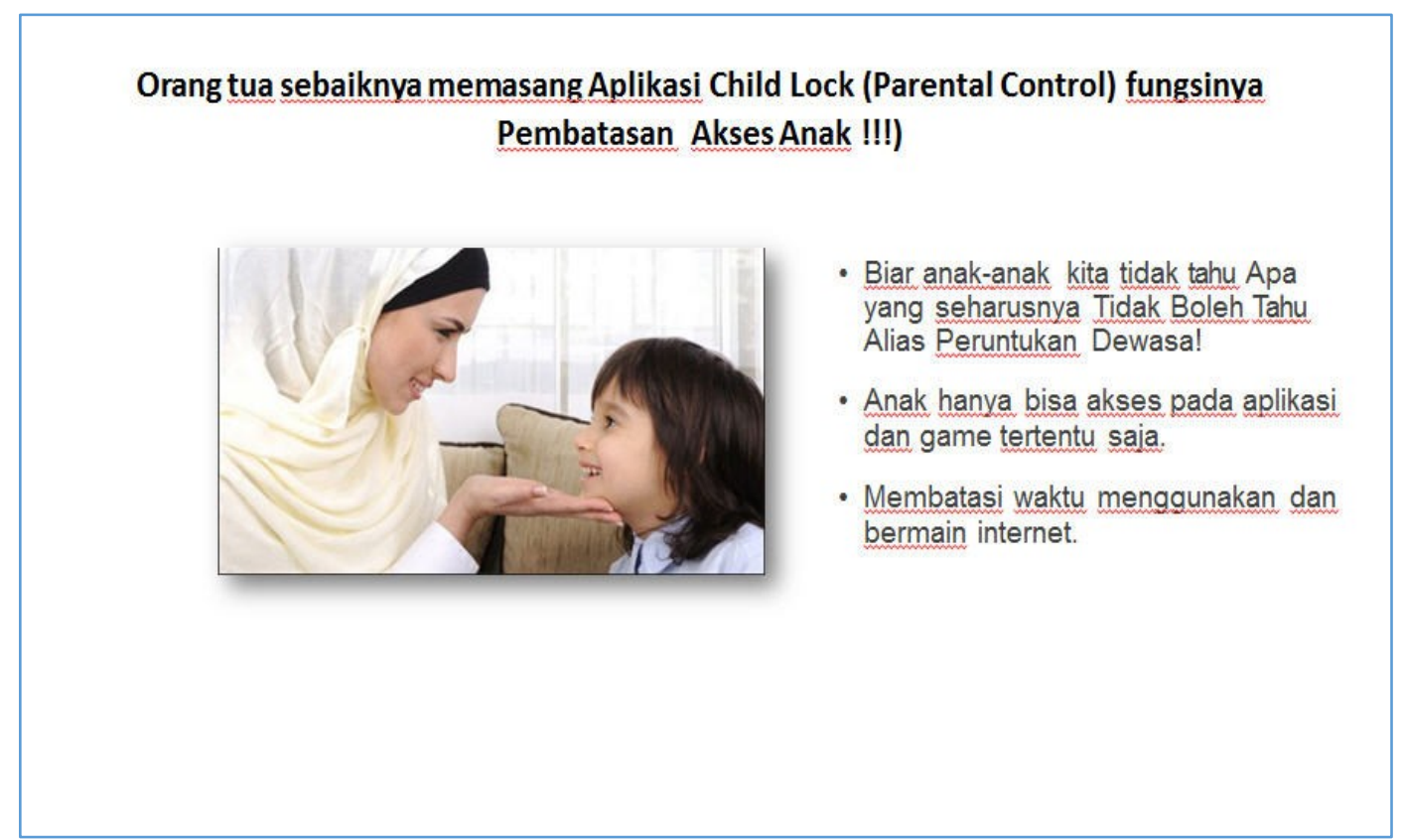

Figure 4. Material Abdimas

Figure 4 and Figure 5 explains that parents instead install the Child Lock application as a function of limiting children's access. Because children don't know what they shouldn't know, children can only access certain apps and games, limiting their time to use and play the internet. 


\section{Yuk Dukung Internet yang Sehat Bagi anak-anak kita}

Salam Insan "Internet sehat dan Aman"!!!

Salam untuk Masa Depan Anak-anak Indonesia!

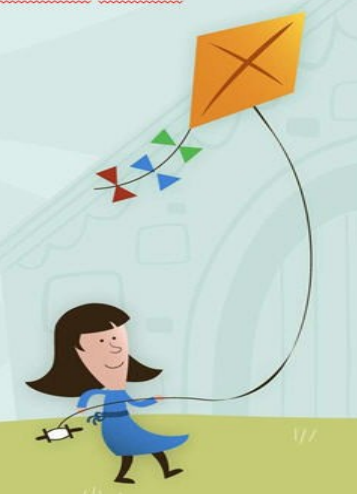

Figure 5. Abdimas Material

The positive and negative impacts of the internet today are increasingly being felt, if you are not wise in using the internet, it may have a negative impact on its users. the presence of the internet, indeed the internet also has many positive impacts on one's activities (Yusron Saudi, 2014). In the past, some activities took a lot of time and effort to complete, but with the presence of the internet, it has made it easier for a person's various activities and work. The existence of the internet increasingly has a significant role in everyday life. Internet users are not only limited to adults but children are also proficient in accessing the internet. What is worrying is the negative impact that the internet will have on children because children do not yet have a strong filter to choose and sort out positive and negative things when accessing the internet. The proof is that in addition to having a positive impact on children, the internet also has many negative impacts on children. The existence of the internet has more or less influenced the character of a child, it is proven that there are many negative things that arise in children who come from the internet.

Figure 6 and 7 show Appearance of abdimas partners and picture of presenter with abdimas participants.

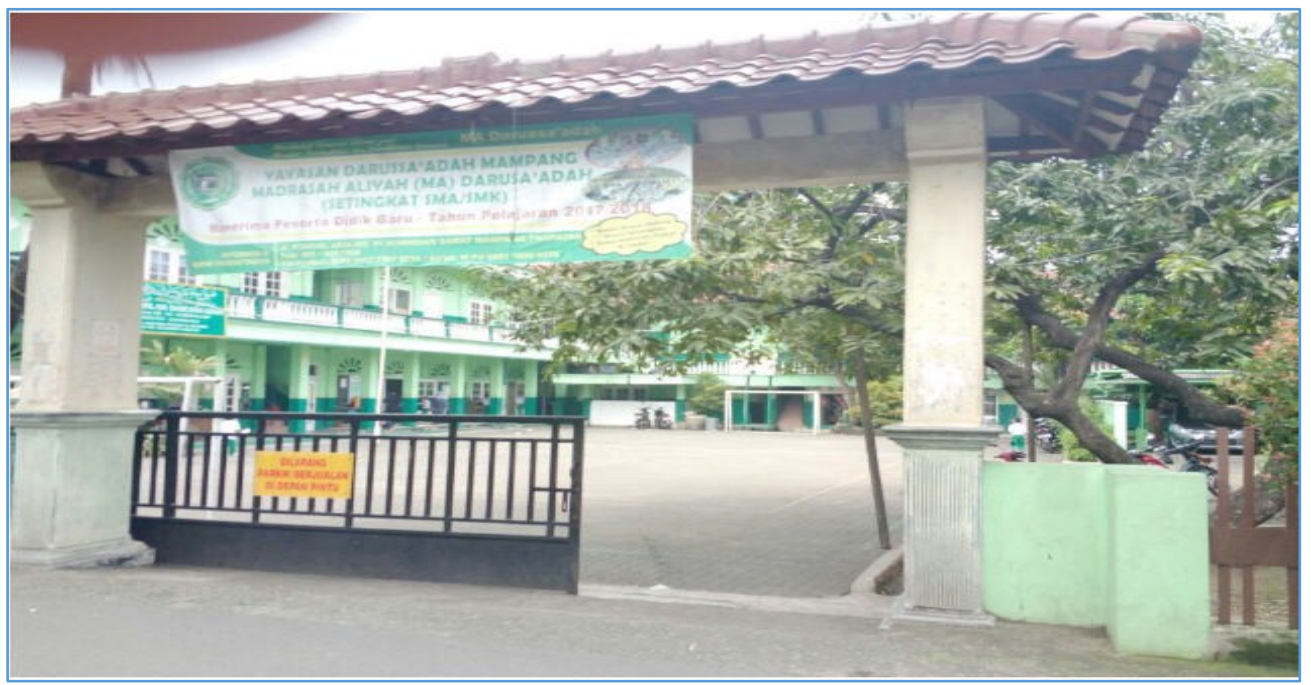

Figure 6. Appearance of abdimas partners. 


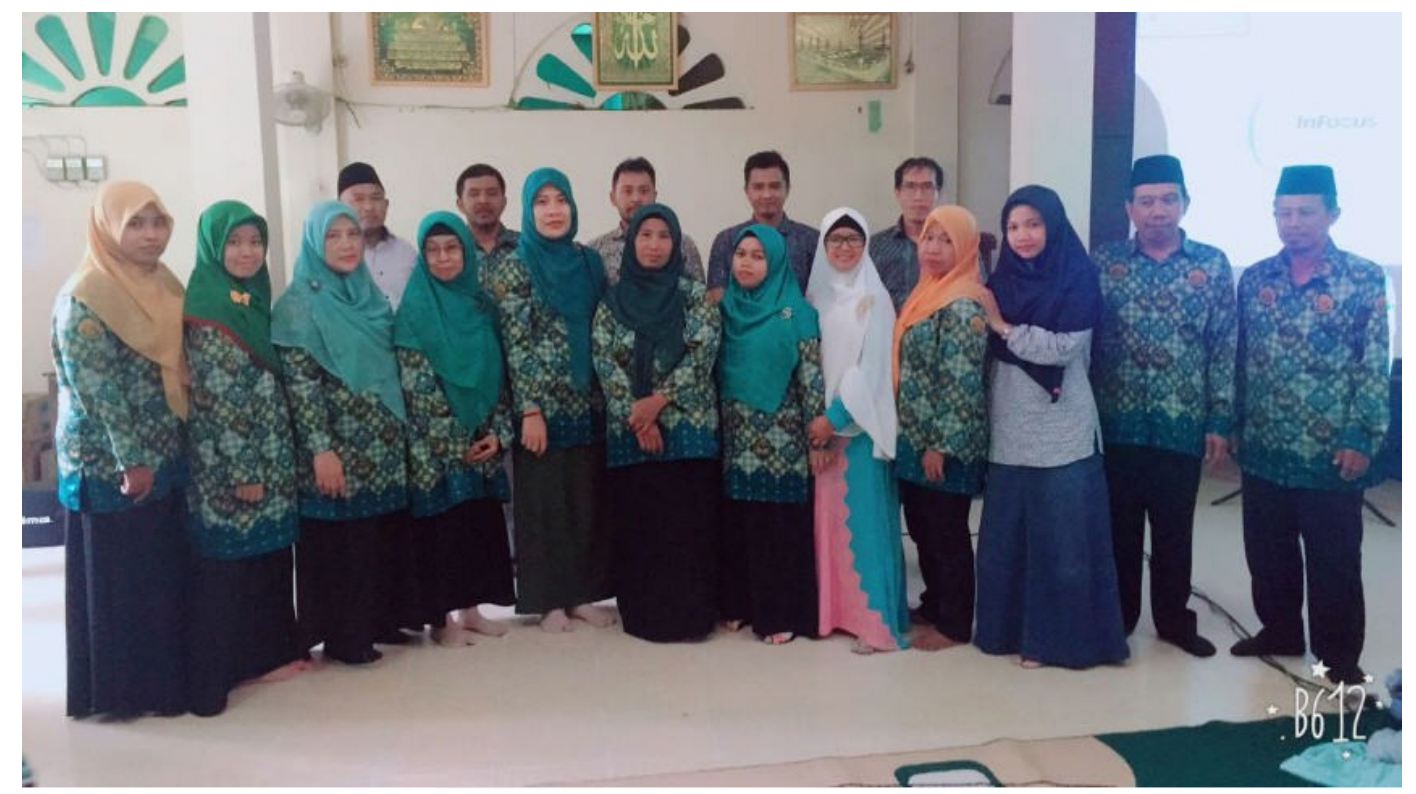

Figure 7. Presenter with Abdimas participants.

The internet is like a double-edged sword for a child, besides having a positive impact, the internet also has a negative impact (Niena, 2017). what are the positive effects of the internet for children and what are the negative impacts of the internet for children? The positive impact of children as follows.

1. Learning resources for children.

2. As a means of entertainment for children.

3. Media socializing children.

4. Children are more sensitive to technological advances.

5. Cultivate children's creativity.

6. Sharpen children's non-verbal skills.

While the negative impact of the internet for children, among others, as follows.

1. The dangers of pornographic content.

2. Internet addiction.

3. Unfiltered information.

4. Children find it difficult to distinguish between real and abstract.

5. Make the child into a person of plagiarism.

6. Children can be individuals who are anti-social.

How to overcome the negative impact of the internet on children

1. Giving children understanding about the negative impact of the internet

2. Accompany children or always supervise children when accessing the internet

3. Give time limit in accessing the internet in a day for children

4. Instilling social values in children that will filter the negative impact of the internet

5. Doing many activities with children such as walking, playing, telling stories and others to reduce children's activities in accessing the internet.

Those are the 6 positive and negative impacts of the internet for children and how to minimize the negative impacts of the internet for children. but actually there are still many positive and negative impacts of the internet on children, but the admin only explained briefly through a review of 6 Positive and Negative Impacts of the Internet for Children (Sukmawati et al, 2013). 


\section{CONCLUSIONS}

Based on the implementation of activities in this service, the following conclusions can be drawn. The parents have awareness to monitor their children activity with gadget, by place PC/Laptop/Hand phone media when children use the internet in the open / easy for parents to monitor, Parents must know \& be smarter in using applications on the internet, Parents and teachers must understand the positive \& negative impacts of internet technology used by children. The internet is "like a double-edged knife for a child", besides having a positive impact, the internet also has a negative impact. Refusing the existence of the internet means refusing progress, the internet is also not something absolutely negative. There are many positive things from using internet technology.

\section{ACKNOWLEDGEMENT}

On this occasion the implementing team would like to thank all parties who have assisted in the proposed program of this activity, starting from the preparation of the proposal, the implementation of the service program until the end of the activity. We would like to thank LPPM UNINDRA for supporting this program proposal, and we would also like to thank the Head of MI Darussa'adah South Jakarta and parents of students.

\section{LIST OF REFERENCE}

Donny B.U, Merry Magdalena. (2009). Internet Sehat, Pedoman Berinternet yang Aman, Nyaman dan Bertanggung Jawab. Seri Literasi Digital (http://internet sehat.id/) diakses tanggal 22 Agustus 2018.

Isa Hariman, Mohammad Sholeh, Catur Iswahyudi. (2016). "Implementasi Metode Internet Sehat Pada Jaringan Komputer Wireless Di Masjid Al Amin Berbah". Jurnal JARKOM Vol. 1 No. 1 Desember 20132013

Niena. (2017), "Aplikasi Kakatu, Bisa Lindungi Anak Dari Pengaruh Negatif Smartphone", https://www.kreasitekno.com/aplikasi-kakatu-bisa-lindungi-anak-dari-pengaruh-negatifsmartphone/, diakses tanggal 11 Juli 2018.

Parenting Indonesia. (2015), "Apa Itu Parental Control?', https://internetsehat.id/2015/06/apa-ituparental-control/, diakses tanggal 16 Juli 2018.

Parenting Indonesia. (2014). "9 Tips Keamanan agar Anak Aman Online", "https://internetsehat.id/2014/09/9-tips-keamanan-agar-anak-aman-online/, diakses tanggal Juli 2018. 
Application of Healthy and Safe Internet in Controlling Negative Internet Impacts for Students at MI Darussa'adah, South Jakarta.

Rizal, Herry Fahrur. (2014). "Lindungi buah hati Anda dari konten pornografi dengan aplikasi Kakatu',https://id.techinasia.com/kakatu-aplikasi-pelindung-anak-dari-pornografi, diakses tanggal Juli 2018.

Rizkia Choiru. (2014). "Kakatu, Mungkinkan Orang Tua Kelola Aplikasi Untuk Anak-anak", http://selular.id/news/startup/2015/10/kakatumungkinkan-orang-tua-kelola-aplikasi-untukanak-anak/ diakses tanggal 11 Juli 2018.

Shinta Isabella. (2016). "Internet Sehat Ubtuj Sekolah Digital", (https://www.researchgate, net/publication/322303192 Internet

Sehat_Untuk_Sekolah_Digital) diakses tanggal 11 Juli 2018.

Sukmawati Nur Endah, Retno Kusumaningrum, Beta Noranita. (2013). "Peningkatan Pengetahuan Internet Sehat dan Aman (INSAN) dalam Program Penyuluhan Berjenjang pada Ibu-Ibu PKK di Kecamatan Tembalang'. Seminar Nasional Ilmu Komputer (SNIK 2016) - Semarang, 10 Oktober 2016 ISBN: 978-602-1034-40-8

Yusron Saudi. (2014), "Materi pelatihan internet sehat. (https://yustonmultimedia.wordpress.com/materi-pelatihan/internet-sehat/) diakses tanggal 28 Juli 2018. 